\title{
Gastric mucosal secretion of interleukin-10: relations to histopathology, Helicobacter pylori status, and tumour necrosis factor- $\alpha$ secretion
}

\author{
K Bodger, J I Wyatt, R V Heatley
}

\begin{abstract}
Background-Interleukin-10 (IL-10) is an $18 \mathrm{kDa}$ peptide with a range of antiinflammatory and immunosuppressive properties.
\end{abstract}

Aim-To determine whether this cytokine is involved in gastric mucosal inflammation in Helicobacter pylori infection.

Methods-The production of IL-10 by antral mucosal biopsy specimens during short term in vitro culture was determined by measuring IL-10 content of supernatants by enzyme linked immunosorbant assay (ELISA). H pylori status was determined by serology and histology, with gastritis scored using the Sydney system. Tumour necrosis factor- $\alpha$ (TNF- $\alpha$ ) content of supernatants was also determined in a subgroup of patients.

Results-IL-10 secretion was significantly greater in patients with $H$ pylori associated chronic gastritis than in patients who were $H$ pylori negative with normal mucosa/reactive changes, and those with $H$ pylori negative chronic gastritis $(p<0.01$ and $<0.05$ respectively). There was a significant correlation overall between IL10 secretion and chronic inflammation score $(r=0 \cdot 40)$. Secretion of TNF- $\alpha$, which was significantly higher in $H$ pylori infected patients than uninfected patients with a normal mucosa $(p<0.04)$, correlated with scores for chronic inflammation and activity $(r=0.39$ and 0.38 respectively), but was only weakly correlated with IL-10 secretion $(r=0 \cdot 22, N S)$. Conclusions-Gastric mucosal production of IL-10 and TNF- $\alpha$ are increased in chronic gastritis associated with $H$ pylori infection, and mucosal cytokine secretion varies with important histopathological aspects of gastric inflammation. Whereas the secretion of $\mathrm{IL}-10$ in $\mathrm{H}$ pylori infection may be protective, limiting tissue damage caused by inflammation, it may also contribute towards failure of the immune response to eliminate the organism.

(Gut 1997; 40: 739-744)

Keywords: interleukin-10, Helicobacter pylori, tumour necrosis factor- $\alpha$.

Histologically, chronic gastritis associated with Helicobacter pylori is characterised by infiltration of the lamina propria by chronic inflammatory cells, the presence of lymphoid follicles, and a variable degree of polymorph infiltration indicative of active inflammation. ${ }^{1}$ The presence of this inflammatory infiltrate suggests a specific immune response directed against the organism. Local cellular immunity, as judged by cytokine production, seems to be activated, with in vitro biopsy studies showing raised mucosal production of proinflammatory cytokines, such as interleukin (IL)-1, IL-6, and IL-8, tumour necrosis factor- $\alpha$ (TNF- $\alpha$ ), and interferon- $\gamma$ (IFN- $\gamma$ ) in subjects with $H$ pylori associated gastritis. ${ }^{2-5}$ Short term biopsy cultures have also confirmed a local humoral response in infected patients, with in vitro mucosal production of $H$ pylori specific immunoglobulins. ${ }^{6}$ Despite this evidence for an intact mucosal immune response to $H$ pylori infection, most people fail to eliminate the organism spontaneously, with infection persisting long term. Although there are probably many factors which contribute to the chronicity of infection, immune suppression or down regulation of local immune reactions is likely to play a part. ${ }^{7} 8$ Bacterial induced immunomodulation, mediated via the release of "inhibitory" cytokines, may contribute to this process. Interleukin-10 (IL-10) is an $18 \mathrm{kDa}$ peptide that was initially described as "cytokine synthesis inhibitory factor" because of its ability to suppress cytokine synthesis in certain T cells. ${ }^{9}$ Specifically, IL-10 suppressed IFN- $\gamma$ and IL-2 production by Th1 cells. Although initially described as a product of the Th2 subset of CD4+ helper cells, in humans IL-10 production has also been shown in Th0 and $T h 1$ cells, CD8+ $T$ cells, activated monocytes, B lymphocytes, and keratinocytes. ${ }^{10-15}$ In vitro, IL-10 shows potent anti-inflammatory properties, including suppression of IL-2 and IFN- $\gamma$ production by $T$ lymphocytes, ${ }^{9} 10$ inhibition of mitogen induced $T$ cell proliferation and of the effector functions of activated monocytes/macrophages, ${ }^{16}$ and inhibition of synthesis and gene expression of TNF- $\alpha$, IL-1, IL- 6 , IL- 8 , and colony stimulating factors in monocytes. ${ }^{17}{ }^{18}$ Hence IL-10 seems to be an important counter regulatory cytokine, perhaps acting as a natural damper of immune responses. The role of IL-10 in the human gastrointestinal tract is largely unknown. Mice deficient in IL-10 develop a chronic enterocolitis, suggesting a possible role for this cytokine in controlling immune responses stimulated by enteric antigens. ${ }^{19} \mathrm{IL}$ 10 gene expression has been shown in intestinal mucosal cells in human inflammatory bowel disease, ${ }^{20}$ and recent work suggests 
that IL-10 is capable of down regulating secretion and mRNA levels of proinflammatory cytokines by inflammatory bowel disease mononuclear phagocytes in vitro. ${ }^{21}$ The role, if any, of IL-10 in the immune response to $H$ pylori infection is currently unknown. We have studied in vitro gastric mucosal secretion of IL10 protein in a series of patients undergoing endoscopy for upper gastrointestinal symptoms.

\section{Methods}

SUBJECTS

Fifty four dyspeptic patients attending for diagnostic endoscopy were recruited, after obtaining informed consent. Patients who had received (within the past month) antibiotics, proton pump inhibitors, bismuth containing compounds, non-steroidal anti-inflammatory drugs (NSAIDs), corticosteroids, or immunosuppressive drugs were excluded, as were patients with a known history of malignancy or immunosuppression. This study was approved by the Leeds Healthcare Clinical research (ethics) committee.

\section{SAMPLE COLLECTION}

A $10 \mathrm{ml}$ sample of venous blood was collected before endoscopy, and serum separated by centrifugation and stored at $-20^{\circ} \mathrm{C}$ until subsequent assay. During upper gastrointestinal endoscopy, multiple biopsy specimens were taken from adjacent sites of the gastric antrum, avoiding areas of macroscopic erosion or ulceration. Two specimens were placed in formalin for histological examination, including Giemsa staining for the presence of $H$ pylori. Histology was subsequently scored by an experienced histopathologist (JIW) using the Sydney system, blinded for results of cytokine estimations. A grade from 0 (absent) to 3 (severe) was assigned for four histological variables namely, inflammation (chronic inflammatory cells), activity (neutrophils), glandular atrophy, and intestinal metaplasia. Four further biopsy specimens were taken for in vitro culture.

IN VITRO CULTURE

Biopsy specimens for in vitro culture were immediately placed in RPMI-1640 culture medium supplemented with $10 \%$ fetal calf serum (Flow Laboratories, Herts, UK), at $37^{\circ} \mathrm{C}$ and transported within one hour to the laboratory. Specimens were then placed in tissue culture chambers containing $1 \mathrm{ml}$ fresh culture medium, and cultured for 24 hours at $37^{\circ} \mathrm{C}$ in a $5 \% \mathrm{CO}_{2}$ humidified incubator. At 24 hours, culture medium was removed, centrifuged, and the supernatant stored at $-20^{\circ} \mathrm{C}$ until assayed. After culture, biopsy specimens were dried on filter papers and weighed as previously described. ${ }^{22}$ In our laboratory, biopsy specimen wet weight has been shown to correlate closely with protein content of specimen homogenates, providing an equivalent correction factor.
INTERLEUKIN-10 ASSAY

Content of IL-10 of culture supernatants was assayed in duplicate using a commercial solid phase enzyme linked immunosorbent assay (ELISA) according to manufacturer's instructions (Quantikine, R\&D Systems, Abingdon, UK). Briefly, culture supernatants were first incubated at room temperature in microtitre wells coated with a murine monoclonal antibody to human IL-10. After washing, a conjugate consisting of an enzyme linked polyclonal antibody specific for interleukin-10 was added to the wells, to sandwich the IL-10 immobilised during the first incubation. Wells were subsequently washed, and a colour reagent (tetramethyl benzidine plus hydrogen peroxide) added. Colour development was stopped using $2 \mathrm{~N}$ sulphuric acid, and the optical density of each well determined with a spectrophotometer set at $450 \mathrm{~nm}$ (wavelength correction $540 \mathrm{~nm}$ ). Sample concentration of IL-10 was determined from a standard curve obtained by assaying a dilution series of recombinant human IL-10 (R\&D Systems). For culture media samples the reported sensitivity of the assay was $1.5 \mathrm{pg} / \mathrm{ml}$, and no cross reactivity with other cytokines has been found.

TUMOUR NECROSIS FACTOR- $\alpha$ ASSAY

Content of TNF- $\alpha$ in culture supernatants was also assayed in duplicate using a commercial ELISA (Genzyme diagnostics, Cambridge, USA $)$ in a subgroup of patients $(n=34)$. Samples were incubated in microtitre wells coated with monoclonal antibody to human TNF- $\alpha$. After washing, a conjugate consisting of a biotin labelled polyclonal antibody to TNF- $\alpha$ was added to the wells, to bind the captured TNF- $\alpha$. Wells were then washed, and a peroxidase labelled streptavidin reagent added which attaches to biotin in the immune complex on the plate. After a further wash, a substrate (peroxide) and chromogen (tetramethyl benzidine) were added, and colour development was stopped with $1 \mathrm{M}$ sulphuric acid. The optical density of each well was determined with a spectrophotometer set at $450 \mathrm{~nm}$, and sample concentration of TNF- $\alpha$ was determined from a standard curve. For culture media samples the reported sensitivity of the assay was $10 \mathrm{pg} / \mathrm{ml}$, and no cross reactivity with other cytokines has been seen.

\section{DETERMINATION OF H PYLORI STATUS}

The presence or absence of $H$ pylori was identified histologically using Giemsa staining. $H$ pylori serology was determined using a commercial ELISA kit for $H$ pylori specific immunoglobulin-G (Helico-G, Shield Diagnostics, Dundee, UK), which has been extensively validated locally. ${ }^{23}$ On the basis of the two tests, patients were divided into three diagnostic groups: (1) "normal group" (normal mucosa or reactive changes only and without histological or serological evidence of $H$ pylori infection, (2) $H$ pylori associated chronic gastritis (chronic gastritis with at least one positive test for $H$ pylori), (3) $H$ pylori negative 
TABLE I Summary of patient characteristics, H pylori status, and histopathology

\begin{tabular}{|c|c|c|c|}
\hline & $\begin{array}{l}\text { Group I } \\
\text { Normal }\end{array}$ & $\begin{array}{l}\text { Group II } \\
\mathrm{HP+}\end{array}$ & $\begin{array}{l}\text { Group III } \\
\text { HP- }\end{array}$ \\
\hline $\begin{array}{l}\text { No of patients } \\
\text { Age (mean (SD)) } \\
\text { M:F } \\
\text { H pylori status } \\
\text { Histology }\end{array}$ & $\begin{array}{l}25 \\
52(21) \\
9: 16 \\
\text { Negative } \\
\text { Normal or reactive } \\
\text { changes only }\end{array}$ & $\begin{array}{l}22 \\
59(20) \\
10: 12 \\
\text { Positive }^{\star} \\
\text { Chronic gastritis }\end{array}$ & $\begin{array}{l}7 \\
60(20) \\
2: 5 \\
\text { Negative } \\
\text { Chronic gastritis }\end{array}$ \\
\hline $\begin{array}{l}\text { Sydney scores (n (\%)): } \\
\text { Inflammation: }\end{array}$ & & & \\
\hline $\begin{array}{l}\text { Absent or mild (grades } 0,1 \text { ) } \\
\text { Moderate or severe (grades 2, 3) } \\
\text { Activity: }\end{array}$ & $\begin{array}{l}25(100) \\
0(0)\end{array}$ & $\begin{array}{r}6(27 \cdot 3) \\
16(72 \cdot 7)\end{array}$ & $\begin{array}{l}5(71 \cdot 4) \\
2(28 \cdot 6)\end{array}$ \\
\hline $\begin{array}{l}\text { Atrophy: } \\
\text { Absent or mild (grades } 0,1 \text { ) } \\
\text { Moderate or severe (grades } 2,3 \text { ) }\end{array}$ & $\begin{array}{c}24(96) \\
1(4)\end{array}$ & $\begin{array}{r}17(77 \cdot 3) \\
5(22 \cdot 7)\end{array}$ & $\begin{array}{l}7(100) \\
0(0)\end{array}$ \\
\hline $\begin{array}{l}\text { Intestinal metaplasia: } \\
\text { Absent or mild (grades } 0,1 \text { ) } \\
\text { Moderate or severe (grades } 2,3 \text { ) }\end{array}$ & $\begin{array}{c}24(96) \\
1(4)\end{array}$ & $\begin{array}{r}17(77 \cdot 3) \\
5(22 \cdot 7)\end{array}$ & $\begin{array}{l}6(85 \cdot 7) \\
1(14 \cdot 3)\end{array}$ \\
\hline
\end{tabular}

* Twenty patients had both histological and serological evidence of $H$ pylori infection; two patients were seropositive only, with chronic active gastritis and pronounced intestinal metaplasia. $\mathrm{HP}+=H$ pylori positive; $\mathrm{HP}-=H$ pylori negative. chronic gastritis (chronic gastritis without histological or serological evidence of $H$ pylori infection).

\section{STATISTICS}

Statistical analysis of IL-10 secretion, expressed as $\mathrm{pg} / \mathrm{g} / 24 \mathrm{~h}$, was performed using a non-parametric test (Mann-Whitney $U$ test), and correlations between in vitro cytokine secretion and histological gradings were analysed using linear regression. A p value $<0.05$ was regarded as significant.

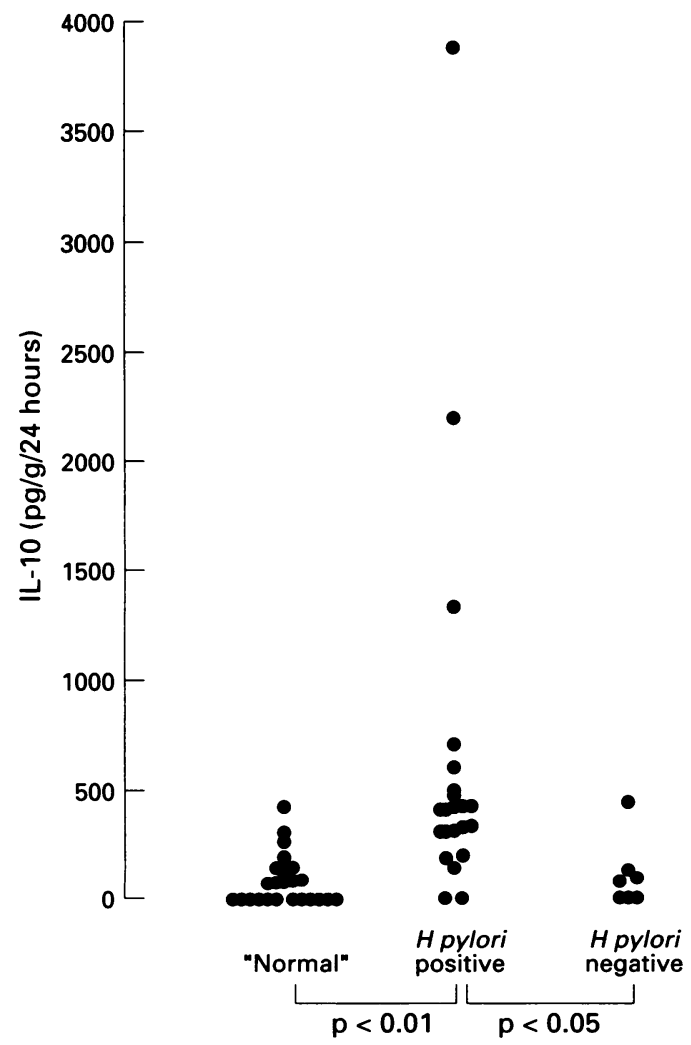

Figure 1: Concentration of IL-10 in 24 hour culture supernatants of antral mucosa in $\mathrm{H}$ pylori negative subjects with normal mucosa or reactive changes only ("normal"), $\mathrm{H}$ pylori associated chronic gastritis ( $\mathrm{H}$ pylori positive), and $\mathrm{H}$ pylori negative chronic gastritis $\mathrm{H}$ pylori negative).

\section{Results}

PATIENT CHARACTERISTICS

Table I summarises the age, sex, $H$ pylori status, and antral histopathology of the patients studied. Twenty five patients had either normal histology or the features of reactive gastritis only, and are designated group I ("normal"); 29 patients had chronic gastritis, of whom 22 were $H$ pylori positive (group II), and seven were $H$ pylori negative both histologically and serologically (group III).

IN VITRO INTERLEUKIN-10 SECRETION

Figure 1 and Table II present the results. Secretion of IL-10 above the detection limit of the assay $(1.5 \mathrm{pg} / \mathrm{ml})$ was found in culture supernatants from $13(52 \%)$ patients in group I, $20(91 \%)$ patients in group II, and four $(57 \%)$ patients in group III, with IL-10 concentrations in supernatants ranging between $2 \cdot 8 \mathrm{pg} / \mathrm{ml}$ and $50 \mathrm{pg} / \mathrm{ml}$. Secretion of IL10 , expressed as $\mathrm{pg} / \mathrm{g}$ tissue weight $/ 24 \mathrm{~h}$, was significantly greater for group II patients (median $411.5 \mathrm{pg} / \mathrm{g} / 24 \mathrm{~h}$; interquartile range (IQR) 309.25-485.5) than for group I (median $75 \mathrm{pg} / \mathrm{g} / 24 \mathrm{~h}$; IQR 0-133), and for group III (median $78 \mathrm{pg} / \mathrm{g} / 24 \mathrm{~h}$; IQR 0-113) ( $\mathrm{p}$ values $<0.01$ and $<0.05$ respectively).

RELATION BETWEEN INTERLEUKIN-10

SECRETION AND HISTOLOGY

Overall, there were significant correlations between IL-10 secretion and the inflammation score $(r=0.40$, Fig 2$)$, activity score $(r=0.26)$ and the intestinal metaplasia score $(r=0.33)$. The relation with intestinal metaplasia score was largely accounted for by an $H$ pylori infected patient with severe intestinal metaplasia having a particularly high IL-10 secretion (3864 pg/g/24 h). Exclusion of this patient from the regression analysis abolished the relation between IL-10 and intestinal metaplasia score, but the correlations with inflammation and activity were not significantly altered.

\section{IN VITRO TUMOUR NECROSIS FACTOR- $\alpha$} SECRETION

Table II and Fig 3 show the results of TNF- $\alpha$ secretion for the subgroup of 34 patients. Secretion of TNF- $\alpha$ was significantly greater in the 12 group II patients than in the 15 patients from group I (median $3219.5 \mathrm{pg} / \mathrm{g} / 24 \mathrm{~h}$ and $1262 \mathrm{pg} / \mathrm{g} / 24 \mathrm{~h}$ respectively, $\mathrm{p}<0.05$ ), and nonsignificantly higher than the seven patients from group III (median $2238 \mathrm{pg} / \mathrm{g} / 24 \mathrm{~h}$ ). There was only a weak correlation between concentrations of secreted TNF- $\alpha$ and IL-10 in these patients $(r=0 \cdot 22$, NS, Fig 4). Secretion of TNF- $\alpha$ was significantly correlated with inflammation score and activity score $(r=0.39$ and 0.38 respectively).

\section{Discussion}

We have successfully measured in vitro IL-10 secretion from normal and inflamed gastric 
TABLE II In vitro gastric mucosal secretion of IL-10 and TNF- $\alpha$

\begin{tabular}{|c|c|c|c|}
\hline & $\begin{array}{l}\text { Group I } \\
\text { Normal }\end{array}$ & $\begin{array}{l}\text { Group II } \\
H P+\end{array}$ & $\begin{array}{l}\text { Group III } \\
H P-\end{array}$ \\
\hline $\begin{array}{l}\text { Median IL-10 secretion (IQR) } \\
\text { (pg/g/24 h) } \\
\text { Median TNF- } \alpha \text { secretion (IQR) } \\
(\mathrm{pg} / \mathrm{g} / 24 \mathrm{~h})\end{array}$ & $\begin{array}{l}75 \\
(0-133) \\
1262 \\
(312 \cdot 5-2952 \cdot 5) \\
(n=15)\end{array}$ & $\begin{array}{l}411 \cdot 5 \\
(309 \cdot 25-485 \cdot 5) \\
3219 \cdot 5 \\
(3066 \cdot 5-7958 \cdot 8) \\
(n=12)\end{array}$ & $\begin{array}{l}78 \\
(156) \\
2238 \\
(0-3236 \cdot 5) \\
(n=7)\end{array}$ \\
\hline
\end{tabular}

$\mathrm{IQR}=$ Interquartile range. $\mathrm{HP}+=H$ pylori positive; $\mathrm{HP}-=H$ pylori negative.

antral mucosa, a phenomenon not previously reported. Furthermore, we have shown that mucosal IL-10 secretion was significantly higher in patients with $H$ pylori chronic gastritis than in patients without infection and with an essentially normal mucosa, as well as in patients with $H$ pylori negative chronic gastritis. Karttunen et al, in a provisional report, have recently found increased expression of IL-10 mRNA in $H$ pylori positive gastritis compared with both normal mucosa and treated $H$ pylori gastritis, supporting our findings. ${ }^{24}$ We have also shown increased TNF- $\alpha$ secretion in $H$ pylori infection, in agreement with earlier studies. ${ }^{2}$ The finding of higher secretion of both IL-10 and TNF- $\alpha$ in $H$ pylori positive versus $H$ pylori negative chronic gastritis in the present study may simply reflect differences in the degree of inflammation between our groups, rather than indicating a specific feature of gastric immune responses to the organism. To allow for the various theoretical sources of IL-10 within inflamed gastric mucosa, we examined in vitro secretion from whole biopsy specimens. Hence the cellular source of IL-10 in our study is unknown. Although in mice the Th2 subset of CD4+ lymphocytes is classically

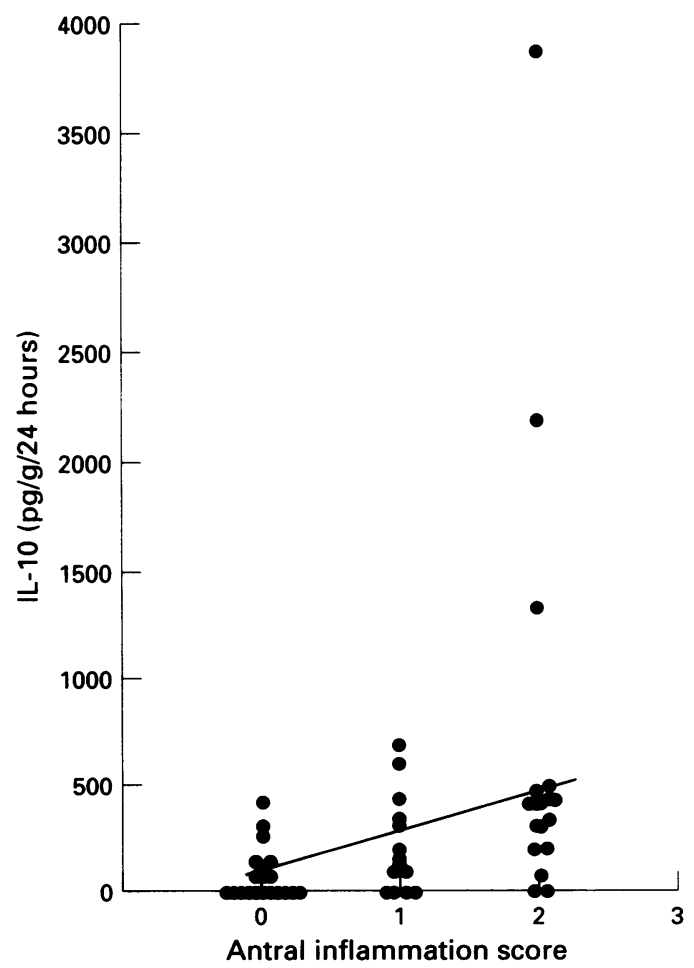

Figure 2: Concentration of IL-10 in 24 hour culture supernatants of antral biopsy specimens versus Sydney score for chronic inflammatory cells ( $n=54$ patients; $r=0 \cdot 40$, $p<0.05)$.

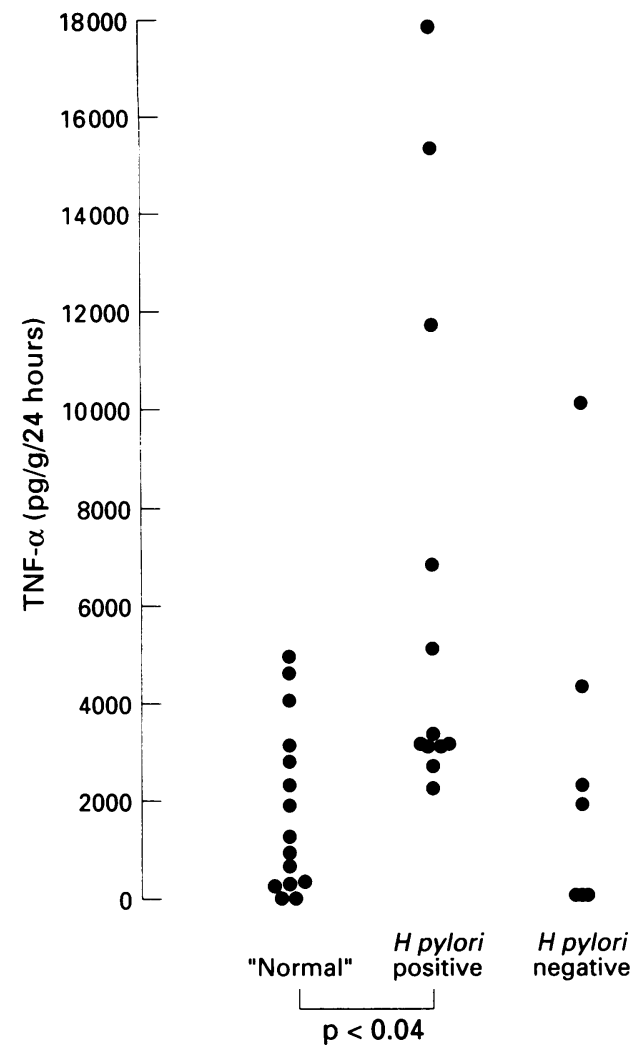

Figure 3: Concentration of TNF- $\alpha$ in 24 hour culture supernatants of antral mucosa in $\mathrm{H}$ pylori negative subjects with normal mucosa or reactive changes only ("normal"), $\mathrm{H}$ pylori associated chronic gastritis (H pylori positive), and $\mathrm{H}$ pylori negative chronic gastritis $(\mathrm{H}$ pylori negative).

associated with IL-10 secretion, in humans a wide variety of cells are capable of producing IL-10, ${ }^{10} 15$ and we would not therefore conclude that raised gastric mucosal secretion of IL-10 necessarily implies a Th2 type response. Furthermore, Th2 cells typically also secrete IL-4, yet Kartunnen et al did not find increased numbers of IL-4 secreting cells in $H$ pylori gastritis. ${ }^{25}$ The likeliest sources of IL-10 in the present study are perhaps mononuclear phagocytes or lymphocytes. The positive

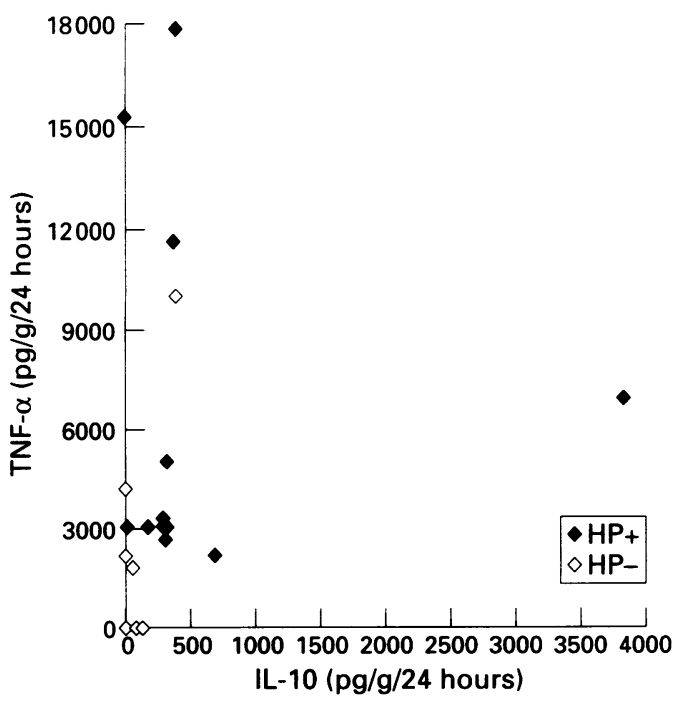

Figure 4: Concentration of TNF- $\alpha$ v IL-10 in 24 hour culture supernatants from patients with $\mathrm{H}$ pylori positive $(H P+)$ and negative $(H P-)$ chronic gastritis. 
correlation we have found between IL-10 secretion and chronic inflammation score, suggests that mononuclear cells are indeed the cellular source of IL-10 in gastric inflammation. Other possible sources of IL-10 include gastric epithelial cells, which are capable of secreting other cytokines (for example, IL-8), ${ }^{26}$ as well as interstitial cells such as intestinal fibroblasts. ${ }^{27}$ Whatever the cellular origin of IL-10 in chronic gastritis, it is interesting to speculate about the possible role of this immunoregulatory cytokine in the local immune response to $H$ pylori infection, and to its possible influence on disease manifestations. We do not know whether the secretion of IL-10 in $H$ pylori gastritis simply represents physiological anti-inflammatory activity, or dysregulation of cytokines in the inflamed mucosa. The first is perhaps the most likely, with IL-10 serving a protective role, reducing local tissue damage caused by inflammation. In vitro, IL-10 inhibits the production of a wide range of proinflammatory molecules and chemokines, such as IL-1, IL-6, and IL-8, TNF- $\alpha$, and IFN- $\gamma,{ }^{11}{ }^{13-15}$ all of which have been implicated in $H$ pylori associated gastritis. ${ }^{2-5}$ We did not find any strong correlation between absolute IL-10 secretion and that of TNF- $\alpha$, although both were correlated with chronic inflammatory cell scores. Clearly the level of activation of mucosal immune cells, the relative proportions of different cell phenotypes, and the presence of other inflammatory mediators will influence the quantity of cytokine secreted rather than cell numbers alone. In addition to damping down local inflammation, the secretion of IL10 may also contribute to the failure of the immune response to eliminate $H$ pylori infection. To survive, the organism may have evolved the propensity to suppress partially the local immune response. Knipp et al have reported a dose dependent reduction in peripheral blood mononuclear cell proliferative responses to mitogen produced by extracts of $H$ pylori, suggesting that the bacterium possesses immunosuppressive properties. $^{8}$ Furthermore, Karttunen et al have found slightly lower $H$ pylori induced DNA synthesis and IFN- $\gamma$ production by peripheral blood mononuclear cells from $H$ pylori infected subjects than for uninfected subjects, ${ }^{28}$ suggesting that perhaps immune responses to the bacterium are attenuated in chronic infection. $H$ pylori induced secretion of immune suppressive cytokines, such as IL-10, may partly explain these phenomena. Secretion of IL-10 has been implicated as a factor associated with adverse disease outcome in bacterial infections. For example, in a murine model of Klebsiella pneumonia, inhibition of IL-10 bioactivity in vivo resulted in enhanced bacterial clearance, increased expression of proinflammatory cytokines, and prolonged survival. ${ }^{29}$ Furthermore, in vivo, the induction of IL-10 synthesis during certain parasitic infections has been suggested as an important strategy by which parasites evade immune destruction..$^{30}$ Impaired antitumour immunity has also been associated with IL-10. ${ }^{31} 32$ It could be postulated that $H$ pylori induced IL10 production, although having the beneficial effect of limiting inflammation in chronic gastritis, could also render local mucosal immune cells less able to mount an adequate defence against malignant cells. There is accumulating evidence to implicate $H$ pylori infection as a cofactor in gastric cancer, ${ }^{33}$ and local immunosuppressive cytokine production in chronic gastritis may provide a further mechanism by which the organism may predispose to the development or progression of malignancy.

In summary, we have shown raised mucosal secretion of IL-10 and TNF- $\alpha$ in $H$ pylori gastritis, with gastric cytokine secretion being higher in patients with more severe chronic inflammation. Whereas the release of IL-10 may be protective, limiting tissue damage caused by inflammation, IL-10 may also contribute to failure of the immune response to eliminate the organism. The effects of IL-10 on the gastric immune response to $H$ pylori, as well as possible implications in gastric cancer, require further investigation.

We thank Drs KL Miloszewski and A Patel for assistance in collecting the biopsy samples, Mrs C Ramsden for technical collecting the biopsy samples, Mrs C Ramsden for technical advice, and Professor PJ Guillou for providing access to laboratory facilities for this study. Part of this work was
presented at the British Society of Gastroenterology Spring meeting in Brighton in March 1996 (Gut 1996; 38 (suppl 1): A30) and at Digestive Diseases Week in San Francisco in May 1996 (Gastroenterology 1996; 110: A868).

1 Heatley RV. Gastritis. In: Heatley RV, ed. Gastrointestinal and hepatic immunology. Cambridge: Cambridge Uniand hepatic immunology.

2 Crabtree JE, Shallcross TM, Heatley RV, Wyatt JI. Mucosal tumour necrosis factor $\alpha$ and interleukin- 6 in patients with Helicobacter pylori associated gastritis. Gut 1991 32: 1473-7.

3 Moss SF, Legon S, Davies J, Calam J. Cytokine gene expression in Helicobacter pylori associated antral gastritis. Gut 1995; 35: 1567-70.

4 Noach LA, Bosma NB, Jansen J, Hoek FJ, van Deventer $\mathrm{SJH}$, Tytgat GNJ. Mucosal tumour necrosis factor $\alpha$, Interleukin-1 $\beta$, and Interleukin-8 production in patients with Helicobacter pylori infection. Scand $f$ Gastroenterol 1994; 29: 425-9.

5 Fan XJ, Chua A, O'Connell MA, Kelleher D, Keeling PW. Interferon- $\gamma$ and tumour necrosis factor production in patients with Helicobacter pylori infection. Ir $\mathcal{F ~ M e d ~ S c i ~}$ 1993; 162: 408-11.

6 Rathbone BJ, Wyatt JI, Worsley BW, Shires SE, Trejdosiewicz LK, Heatley RV, et al. Systemic and loca antibody responses to gastric Campylobacter pyloridis in non-ulcer dyspepsia. Gut 1986; 27: 642-7.

7 Lee A. The nature of Helicobacter pylori. Scand $f$ Gastroenterol 1996; 31 (suppl 214): 5-8

8 Knipp U, Birkholz S, Kaup W, Opferkuch W. Immune suppressive effects of Helicobacter pylori on human peripheral blood mononuclear cells. Med Microbiol Immunol (Berl) 1993; 182: 63-76.

9 Fiorentino DF, Bond MW, Mosmann TR. Two types of mouse helper T-cell. IV. Th2 clones secrete a factor that inhibits cytokine production by Th1 clones. $\mathcal{f} \operatorname{Exp} M e d$ 1989; 170: 2081-95.

10 Del Prete G, De Carli M, Almerigogna F, Giudizi MG Biagiotti R, Romagnani S. Human interleukin-10 is produced by both type 1 helper (Th1) and type 2 helper (Th2) $\mathrm{T}$ cell clones and inhibits their antigen-specific proliferation and cytokine production. F Immunol 1993; 150: $353-60$.

11 de Vries JE. Immunosuppressive and anti-inflammatory properties of interleukin-10. Ann Med 1995; 27: 537-41.

12 Burdin N, van Kooten C, Galibert L, Abrams JS. Endogenous IL-6 and IL-10 contribute to the Endogenous IL-6 and IL-10 contribute to the
differentiation of CD40- $\alpha$ activated B lymphocytes. $f$ Immunol 1995; 154: 2533-44.

13 Moore KW, O'Garra A, de Waal Malefyt R, Veira P, Mosmann TR. Interleukin-10. Ann Rev Immunol 1993; 11: $165-90$

14 Rennick D, Berg D, Holland G. Interleukin-10: an overview. Progress in Growth Factors Research 1992; 4: 207-27.

15 de Waal Malefyt R, Yssel H, Roncarolo MG, Spits H, de Vries JE. Interleukin-10. Curr Opin Immunol 1992; 4 314-20. 
16 de Waal Malefyt R, Haanen J, Spits $H$, Roncarolo MG, de Velde A, Figdor CG, et al. Interleukin 10 (IL-10) and viral IL-10 strongly reduce antigen-specific human $T$ cell proliferation by diminishing the antigen-presenting capacity of monocytes via down-regulation of class II major histocompatability complex expression. 7 Exp Med major histocompat

17 Fiorentino DF, Zlotnik A, Mosmann TR, Howard M, O'Garra A. Interleukin-10 inhibits cytokine production by activated macrophages. I Immunol 1991; 147: 3815-22

18 de Waal Malefyt R, Abrams J, Bennett B, Figdor CG, de Vries JE. Interleukin-10 (IL-10) inhibits cytokine synthesis by human monocytes: an autoregulatory role of interleukin- 10 produced by human monocytes. $7 \operatorname{Exp} M e d$ 1991; 174: 2109-20.

19 Kuhn R, Lohler J, Rennick D, Rajewsky K, Muller W Interleukin-10 deficient mice develop chronic enterocolitis. Cell 1993; 75: 263-74.

20 Radford-Smith G, McGowan I, Jewell DP. Th1 and Th2 gene expression in inflammatory bowel disease. Gastroenterology 1994; 106: A757.

21 Schreiber S, Heinig T, Thiele HG, Raedler A. Immunoregulatory role of Interleukin-10 in patients with inflammatory bowel disease. Gastroenterology 1995; 108: 1434-44.

22 Wardle TD, Hall L, Turnberg LA. Platelet activating factor: release from colonic mucosa in patients with ulcerative colitis and its effect on colonic secretion. Gut 1996; 38 : 355-61.

23 Sobala GM, Crabtree JE, Penrith JA, Rathbone BJ, Shallcross TM, Wyatt JI, et al. Screening dyspepsia by Shallcross TM, Wyatt JI, et al. Screening dyspepsia by
serology to Helicobacter pylori. Lancet 1991; 338: 94-6.

24 Karttunen R, El-Zaatari FAK, Karttunen TJ, El-Zimaity H, Yousfi MM, Graham DY. Expression of mRNA for gamma interferon, interleukin-10 and interleukin-12 in $\mathrm{HP}$-infected and non-infected gastric mucosa. Gastroenterology 1995; 108: A128.
25 Karttunen R, Karttunen T, Ekre H-P T, MacDonald TT. Interferon-gamma and interleukin- 4 secreting cells in the gastric antrum in Helicobacter pylori positive and negative gastritis. Gut 1995; 36: 341-5.

26 Crabtree JE Farmery SM, Lindley IJD, Figura N, Peichl P, Tompkins DS. CagA/cytotoxic strains of Helicobacter pylori and interleukin-8 in gastric epithelial cells. $f$ Clin pylori and interleukin-8
Pathol 1994; 47: 945-50.

27 Pang G, Couch L, Batey R, Clancy R, Cripps A. GM-CSF, interleukin-1 $\alpha$, interleukin-1 $\beta$, interleukin- 6 , interleukin-8, interleukin-10, ICAM-1 and VCAM-1 gene expression and cytokine production in human duodenal fibroblasts stimulated with lipopolysaccharide. Clin Exp Immunol 1994; 96: 437-43.

28 Karttunen R, Andersson G, Poikonen K, Kosunen TL, Karttunen $\mathrm{T}$, Juutinen $\mathrm{K}$, et al. Helicobacter pylori induces lymphocyte activation in peripheral blood cultures. Clin Exp Immunol 1990; 82: 485-8.

29 Greenberger MJ, Strieter RM, Kunkel SL, Danforth JM, Goodman RE, Standiford TJ. Neutralization of IL-10 increases survival in a murine model of Klebsiella pneumonia. F Immunol 1995; 155: 722-9.

30 Gazzinelli RT, Oswald IP, James SL, Sher A. IL-10 inhibits parasite killing and nitrogen oxide production by IFN- $\gamma-\alpha$ activated macrophages. $\mathcal{F}$ Immunol 1992; 148: $1792-6$.

31 Kambayashi T, Alexander HR, Fong M, Strassmann G. Potential involvement of IL-10 in suppressing tumorssociated macrophages. Colon-26-derived prostaglandin E2 inhibits TNF- $\alpha$ release via a mechanism involving ILE2 inhibits TNF- $\alpha$ release via a mecha

32 Beissert S, Hosoi J, Grabbe S, Asahina A, Granstein RD IL-10 inhibits tumor antigen presentation by epidermal antigen-presenting cells. $\mathcal{f}$ Immunol 1995; 154: 1280-6

33 Webb PM, Forman D. Helicobacter pylori as a risk factor for cancer. Baillieres Clin Gastroenterol 1995; 9: 563-82 